Roy-Chaudhury, Rahul and Sullivan de Estrada, Kate (2018) 'India, the Indo-Pacific and the Quad', Survival, Vol. 60, No. 3 (June-July), pp. 181-94.

DOI 10.1080/00396338.2018.1470773

\title{
India, the Indo-Pacific and the Quad
}

\section{Rahul Roy-Chaudhury and Kate Sullivan de Estrada}

The term 'Indo-Pacific', recently in fashion, describes a supposedly vital and contiguous strategic arena encompassing the eastern Indian and Western Pacific oceans. Accompanying the concept is the notion of a revived partnership: the Quadrilateral Security Dialogue between the United States, Australia, India and Japan (or 'Quad'). One of these countries is not like the others. India's maritime interests and strategy sit uneasily with those of the other Quad powers. India's is an Indian Ocean vision, rather than an Indo-Pacific vision. Bound by the strategic primacy of the Indian Ocean and by the constraints on its sea-power projection, in the short term, India's engagement with the IndoPacific framework will remain largely diplomatic, economic and rhetorical. India's core strategic focus lies west of the Strait of Malacca.

\section{The return of the Quad}

The Quad, previously initiated in 2007 by Japanese Prime Minister Shinzo Abe and discontinued after the withdrawal of Australia under then-prime minister Kevin Rudd, was revived at a meeting of senior diplomats from the four nations on the sidelines of the ASEAN summit in Manila in November 2017, resulting in parallel commitments to maintain a free and open order in the Indo-Pacific. ${ }^{1}$ The IndoPacific construct is partly material, reflecting a vast increase in activity along the sea lines of communication that link the two oceanic regions in trade and energy - and in turn, it is partly strategic, as this greater interdependence brings greater vulnerability and risk.

Yet the currency of the Indo-Pacific idea lies also in its framing as a space of shared values. Prime Minister Abe's now widely cited 'Confluence of the Two Seas' speech, delivered before the Indian parliament in 2007, spoke not only of the 'dynamic coupling' of the Indian and Pacific oceans, but also of their identity as 'seas of freedom and of prosperity'. ${ }^{2}$ Australia's 2017 foreign-policy White Paper referred to a vision of an 'open, inclusive and prosperous Indo-Pacific region, in which the rights of all states are respected'. ${ }^{3}$ US President Donald Trump's five-nation tour of Asia late last year was punctuated by his frequent invocation of the phrase 'free and open Indo-Pacific region'. ${ }^{4}$ And India's press release in response to the November quadrilateral meeting declared that 'a free, open, prosperous and inclusive Indo-Pacific region serves the long-term interests of all countries in the region and of the world at large'. 5

Two ideas are implicit in this values-based framing: one about China, the other about India. Firstly, despite claims from the White House that the term is 'certainly not' ${ }^{6}$ an effort to contain China's influence, it is clear that the Indo-Pacific construct is a response to perceptions that China is deploying infrastructure development and investments in the region for geopolitical gain, and that Beijing is, at best, weakly committed to a rules-based international order, particularly in the maritime domain. Secondly, in a way that the term 'Asia-Pacific' did not, 'Indo-Pacific' explicitly includes a rising India, whose significance to the future balance of power in Asia is obvious, and whose democratic credentials and rhetorical embrace of a rules-based order offer reassurance to Washington, Tokyo and 
Canberra. As a senior Trump-administration official put it, 'We talk about an Indo-Pacific in part because that phrase captures the importance of India's rise'.

External recognition of India's growing influence and hopes for its cooperation in upholding freedom of navigation and overflight at sea resonate, in theory, with Indian ambitions. In recent years, a key part of India's rise has been a turn to the sea; its 2015 Maritime Security Strategy, for example, notes 'the incontrovertible link between secure seas and India's resurgence in the 21 st century'. The language of Indo-Pacific summitry also chimes with India's rhetorical commitment to an open maritime order. ${ }^{8}$

Nevertheless, there are clear limits to India's enthusiasm for the Quad. For India, Japan and Australia alike, the fear of provoking China at a moment when US commitment to the security of the region is uncertain is a reason for caution. Beyond that shared caution, New Delhi has its own historical aversion to multilateral arrangements that can be construed as alliances, and has been ambivalent towards democratic collectives. The current Indian government, perhaps even more than its predecessors, also places great value on India's relationships with ASEAN member states through a revamped 'Act East' policy. This explains why the Indian government's press release following the Manila meeting in November avoided any explicit mention of a 'quadrilateral', unlike the US and Australian statements. (For that matter, it is noteworthy that four separate statements were issued by the four governments after the Manila meeting, rather than a single, joint statement.) ${ }^{9}$ Nor did it mention freedom of navigation and overflight, respect for international law or maritime security, although New Delhi has in the past regularly voiced support for these principles. ${ }^{10}$ The press release also clarified that Act East remains 'the cornerstone of [the Indian government's] engagement in the Indo-Pacific region'. ${ }^{11}$

Beyond this diplomatic inhibition, however, is something more fundamental: India's own idea of its maritime interests and strategy may not match the expectations of other Quad members.

\section{Mapping the Indo-Pacific}

The four Quad capitals define the Indo-Pacific differently. The US National Security Strategy, released in December 2017, states that the Indo-Pacific region 'stretches from the west coast of India to the western shores of the United States' and thereby neatly slices off the western Indian Ocean. ${ }^{12}$ The regional map on the cover of the 2017 Australian foreign-policy White Paper highlights an area that extends just far enough to include the westernmost point in India and then arches southwards to exclude much of the western Indian Ocean. ${ }^{13}$

By contrast, the 2017 edition of Japan's Diplomatic Blue Book maps an Indo-Pacific that stretches from Japan, in the east, to the east coast of the African continent, in the west, including both the eastern and the western Indian Ocean. Japan and India do share a preference for cross-regional trade and infrastructural connections, as expressed in a May 2017 vision document for an Asia-Africa Growth Corridor, which some view as a bilateral response to China's Belt and Road Initiative (BRI). ${ }^{14}$ But partnering on economic cooperation is about as far as India is willing to go. The 2015 Maritime Security Strategy specifically lists India's 'primary areas of maritime interests' as extending from, at the most westerly points, the Persian Gulf and the Gulf of Oman; the Gulf of Aden and the Red Sea; the east coast of Africa littoral and the southwest Indian Ocean region island nations to, at the most easterly reach, the Andaman Sea to India's east, whose littoral states include Myanmar, Thailand and Indonesia. ${ }^{15}$ India's strategy document also lists around ten choke points that sit at the entry and exit points to, and the thoroughfares across, the Indian Ocean. The southeast Indian Ocean (stretching as 
far as Australia), South and East China seas, western Pacific Ocean, and southern Indian Ocean region (including Antarctica), are relegated to the status of 'secondary areas of maritime interest'.

\section{The primacy of the Indian Ocean}

The Indian Ocean's importance for India has a great deal to do with the nature of the country's rise. India's primarily economics-driven emergence has seen a marked increase in trade flows and a growing dependence on the transport of energy and raw materials, both of which depend primarily on sea lines of communication. ${ }^{16}$ Pakistan's growing partnership with China has also helped ensure that New Delhi's rising ambitions have not been focused on land-based pre-eminence. The result is a new appreciation of the link between India's maritime development and its national power, illustrated by the burgeoning interest among contemporary Indian strategists in the writings of the nineteenthcentury American naval theorist Rear-Admiral Alfred Thayer Mahan. ${ }^{17}$

More recently, a major driver of India's seaward turn has been China's expanding influence in the Indian Ocean through the launch of the BRI. The initiative's flagship project, the $\$ 62$ billion ChinaPakistan Economic Corridor (CPEC), seeks to link China to the Indian Ocean through Pakistan's Gwadar port. In parallel, the BRI's Maritime Silk Road traverses key strategic nodes across the Indian Ocean. China's BRI is an affront to India, which believes that by virtue of simple geography it has a right to maritime pre-eminence in the Indian Ocean.

Although from the 1980s onwards India's leaders began to recognise the Indian navy's potential as an instrument of state power, it was not until the beginning of the twenty-first century that India's ocean geography began to receive the attention of its leadership. That decade saw, as David Scott puts it, 'a shift of maritime vision from a small coastal-hugging passive brownwater fleet to a larger oceangoing active blue-water fleet capable of power projection throughout the Indian Ocean'. ${ }^{18}$

Under the current leadership of Prime Minister Narendra Modi, India for the first time aspires to become a 'leading' power in the Indian Ocean, seeking to take on greater roles and responsibilities in the region. In March 2015, Modi engaged in a purposeful spree of island hopping, visiting the Seychelles (the first ministerial visit in 34 years), Sri Lanka (the first in 28) and Mauritius, where Modi became the first Indian prime minister in decades to unveil an Indian Ocean vision.

That vision, declared Modi, 'is rooted in advancing cooperation in our region; and, to use our capabilities for the benefit of all in our common maritime home'. ${ }^{19}$ His plan centres on shared maritime-security capabilities and mutual economic development, joint action in response to emergencies, and adherence to international maritime rules and norms. Buried in this rhetoric is a pitch for regional connectivity distinct from that offered by China. India refused to participate formally in China's May 2017 BRI forum, citing objections to CPEC as a project that 'ignores [India's] core concerns on sovereignty and territorial integrity' (since it incorporates a highway that traverses territory claimed by India) as well as objections to BRI more broadly, for what India believes is absent: 'universally recognized international norms, good governance, rule of law, openness, transparency and equality'. ${ }^{20}$ At a conference in Colombo in September of that same year, Indian officials pressed for a collective definition of Indian Ocean 'identity'. ${ }^{21}$ India's Foreign Secretary S. Jaishankar declared, pointedly, that the Indian Ocean 'must be treated as a partner, not as an arena' ${ }^{22}$ that it was 'naturally supportive of international norms and rule of law', and 'the world's only English-speaking ocean region'. ${ }^{23}$ The implication of the language, albeit phrased diplomatically, is clear: China is not a natural part of the Indian Ocean. 
For Modi, apart from the insistence that the region not be Chinese, the scope of the claim that the Indian Ocean is India's ocean has two further dimensions: economics and counter-terrorism. Modi has launched significant initiatives to develop India's port infrastructure, seeking to use the civilian maritime sector as a driver of employment and economic growth. ${ }^{24}$

He has also placed an emphasis on coastal and maritime security in counterterrorism. (Both India's deadliest terror attack, in March 1993 in Bombay, and the November 2008 attack on Mumbai, were seaborne.) The Modi government has overhauled coastal security, and maritime-domain awareness is a central theme in the 2015 Maritime Security Strategy. This twin emphasis on development and security at home, however, points to a pervasive theme in India's rise and power projection under Modi's leadership: a recognition of limited capabilities and certain kinds of vulnerabilities, and an eagerness to consolidate and build up strength - but not to overstretch. Similarly, the desire to operate away from Chinese influence underscores the importance of the Indian Ocean, but diminishes the logic of projecting Indian power further eastwards, within or close to China's territorial waters. The Indian navy's activities have followed this logic. The navy has clear incentives for a strong operational role in the Indian Ocean and little such incentive for a role that extends to the South China Sea or the broader Pacific Ocean. Meanwhile, it has been pushing back on Chinese presence closer to home.

\section{China: pushback and challenges}

In 2017, China established for the first time a permanent naval presence in the Indian Ocean through its first overseas military base in Djibouti, on the Horn of Africa. New Delhi's concerns centre on both Beijing's increasingly assertive policies and China's growing influence in the Indian Ocean, which appears to India as a strategy of encirclement. China's initiatives include port-development projects at Hambantota and Colombo in Sri Lanka, Gwadar in Pakistan, Chittagong in Bangladesh, Kyaukpyu in Myanmar, and reports of the leasing of islets for this purpose in the Maldives, as well as a significant increase in naval deployments in the Indian Ocean, including submarine visits to the ports of Colombo and Karachi. China is also emerging as a supplier of critical naval hardware in the region: it sold two refurbished diesel-electric submarines to Bangladesh in November 2016 and is constructing eight submarines for Pakistan. ${ }^{25}$

India is responding in a number of ways - but each comes with its own challenges. Firstly, it aims to selectively challenge China's infrastructure projects in South Asia with Indian alternatives, including economic support, and port and energy development. In April 2017, for example, India agreed to provide its third line of credit to Bangladesh for $\$ 4.5 \mathrm{bn}$, including for port upgrades, having provided \$1bn in 2010 and \$2bn in 2016. The two countries settled their maritime-border dispute in July 2014 and their land-border dispute in June 2015. India is also pursuing a \$2bn investment in Sri Lanka for the development of the port, oil terminals and refinery at Trincomalee; it is also in talks to invest in an airport near Hambantota.

Secondly, India has made a point of appearing as one of the first contributors to humanitarian and disaster-relief operations in its neighbourhood. A key unspoken message of these missions is of India's proximity and preparedness to step in vis-à-vis China. Thirdly, New Delhi has sought to expand bilateral maritime-security and -defence cooperation with island and littoral states, building on the work of the previous Congress-led government, which provided naval vessels and aircraft to select states while carrying out joint surveillance, patrols and hydrographic surveys of the exclusive economic zones (EEZs) of Mauritius, the Seychelles and the Maldives. The Modi government has provided defence-related lines of credit, and overseen the launch of a coastal-surveillance radar 
project in the Seychelles; it plans construction and upgrading of an airstrip and jetty on the Mauritian island of Agaléga and Assumption Island in the Seychelles for surveillance purposes. ${ }^{26}$ That said, India faces difficulties in these bilateral partnerships. The Indian government's complicated relationship with the Maldives' authoritarian president, Abdulla Yameen, has been exacerbated by Yameen's outreach towards China. The result is that India's three existing radar stations in the Maldives, connected to India's coastal radar network, are unlikely to be operational, and plans for the construction of seven additional Indian radars in the Maldives are on hold. Indian territory, in the form of Minicoy Island, begins just 90 nautical miles from the northernmost island of the Maldives, and even a medium-range Chinese surveillance radar in the northern Maldives (should the Maldives government allow one to be stationed there) could monitor air activity over India's entire southern peninsula. In the case of Sri Lanka, Indian anxieties centre on the political and security impact of Colombo's indebtedness to China and the December 2017 debt-for-equity swap that has resulted in a Chinese company's control of the Hambantota port. Meanwhile, there is concern in the Seychelles over the Indian construction of a Seychelles coastguard facility on Assumption Island, with a leak in March 2018 of the secret revised India-Seychelles agreement stalling its ratification by the Seychelles parliament. Fourthly, as China has stepped up assertive patrolling in the South China Sea and increased naval deployments in the Indian Ocean, concerns in New Delhi about active patrols by nuclear-powered Chinese submarines have resulted in a greater emphasis on nuclear deterrence at sea. ${ }^{27}$ This has led to a larger role for Indian surveillance and an acceleration of India's drive to put nuclear weapons to sea. The 2015 Maritime Security Strategy underscores that India's nuclearpowered ballistic-missile submarines (SSBNs) aim to give the country's nuclear deterrent 'credibility, effectiveness and survivability'. ${ }^{28}$ The Arihant, commissioned in 2016 and expected to be the first of five such vessels, carries ballistic missiles with a range of 700 kilometres, with longer-range ballistic missiles of 3,000-5,000km currently under development. ${ }^{29}$

The Arihant, however, has been in dock for over a year undergoing repairs following an accident. More broadly, its operational deployment brings specific challenges. In order to prevent accidents and targeted attacks, India's non-sea-based nuclear weapons have traditionally been de-mated, with warheads physically separated from the delivery platforms of aircraft and ballistic missiles. Even if this is still the case for the Arihant, de-alerting at sea is unlikely to continue indefinitely, as the rationale for India's sea-based nuclear deterrent is to ensure a 'second-strike' capability. This will require its nuclear weapons and missiles to be pre-mated with the delivery vehicle (or 'canisterised') to form a ready arsenal. Such an arrangement, however, increases vulnerability both to accidents and to targeted attacks at dedicated naval facilities.

Ensuring a high degree of reliability in communication with the submarine at sea is another challenge. The importance of communication at a time of crisis is key. In the event that - unlike nuclear weapons on land or in the air - the submarine's communication from land suddenly ends and alternative means of communication are not successful, it is not clear what action the submarine commander should take. In such circumstances, if political control over nuclear weapons is essential, as required by India's nuclear doctrine, deterrence is likely to fail; but, if deterrence is not to fail, then political control needs to be 'weakened' or transferred to the submarine itself. Neither of these options currently appears acceptable.

\section{Beyond the Indian Ocean: ambition and constraint}

In terms of declaratory policy and defence diplomacy, India is certainly looking beyond the Indian Ocean, which helps explain why it is amenable to participating in the Quad, even if it remains reluctant to call it that. India has sought to significantly upgrade its bilateral strategic partnerships 
with the United States, Japan, Australia and Vietnam. In August 2016, India signed a memorandum of understanding with the United States to provide mutual military access to each country's support facilities, and in December 2016, the US accorded India the status of a 'major defence partner'. India and Japan upgraded their relationship to a 'special strategic and global partnership' in September 2014, institutionalising engagement through various ministerial dialogues. Relations with Australia were upgraded to the level of 'strategic partnership' in 2009, and defence cooperation was expanded in November 2014 to include research, development and industry engagement, with regular defenceministerial meetings. India provided nine ships to the 2017 iteration of the trilateral Malabar exercise with the US and Japanese navies in the Bay of Bengal, its largest-ever contribution. India has also provided Vietnam with patrol boats, a $\$ 500$ million line of credit for defence spending, access to satellite data for monitoring its own waters, and submarine and combat-aircraft training. A 2018 bilateral joint statement called for strengthening of cooperation in anti-piracy, security of sea lanes and exchange of white-shipping information (data on merchant or cargo ships). ${ }^{30}$

The Modi government has also stepped up its engagement with ASEAN. A joint statement at the January 2018 ASEAN-India Summit in Delhi sought to strengthen maritime cooperation, ${ }^{31}$ and the biannual Milan exercise took place off the coast of the Andaman and Nicobar Islands, involving the participation of Indonesia, Singapore, Malaysia and Thailand. However, India's embrace of ASEAN, and the importance that the organisation holds in India's 'Act East' strategy, in itself poses an obstacle to India's embrace of the Quad, as India has traditionally supported ASEAN's centrality in matters of regional security. ${ }^{32}$

A similar pattern of rhetorical ambition and practical constraint is visible in India's attitude towards the South China Sea. Indian statements and strategy documents are replete with references to freedom of navigation and overflight, focusing on unimpeded lawful maritime commerce in the South China Sea in accordance with international law, as well as seeking the peaceful resolution of maritime disputes in the region. It is highly unlikely, however, that an Indian government would order the navy to operationally deploy in the South China Sea to protect India's commercial interests. India is also unlikely to carry out freedom-of-navigation operations (FONOPS) in the South China Sea, especially as India itself remains a target of US FONOPS over the issue of prior consent required for military exercises or manoeuvres in India's EEZ or operations at sea. India will almost certainly continue to reject formal invitations to join the United States in joint patrols in the South China Sea. Apart from significant volumes of maritime trade, the only asset India holds in the region is in Vietnam, with Indian oil firm ONGC Videsh conducting oil and gas exploration and exploitation activities on land, on its continental shelf and within its EEZ.

Moreover, even India's strategy in the Indian Ocean can only operate as far as the constraints set by India's naval-expansion programme. The ambitious warship-building programme reportedly seeks to develop a 212-ship navy within the next ten years, up from 138 ships at present (14 submarines, 27 principal surface combatants and nearly 100 patrol and coastal combatants). Virtually all of this is to be based on domestic warship construction, with some 40 ships currently being built in India. ${ }^{33}$ India's warship-construction projects, however, continue to suffer from innumerable delays and cost increases. Moreover, only a quarter of the warships currently being built are principal combatants (including aircraft carriers, nuclear-armed ballistic missile and conventional submarines, and destroyers and frigates).

Meanwhile, the navy is overstretched, compromising its operational effectiveness. A prominent example is the conventional submarine force, where India's total number of submarines is in decline with no follow-on acquisition programme in place. This situation is compounded by the lack of an 
adequate number of multi-role helicopters and minesweepers. India's defence budget for 2018-19 indicates a nominal increase of $9.5 \%$ for the capital side of the armed forces, just about covering $5 \%$ inflation and rupee depreciation, resulting in a real increase of less than 5\%, with much of it to be spent to cover payments for ongoing acquisitions. ${ }^{34}$ India has also, so far, made only partial use of the Andaman and Nicobar Islands in the Bay of Bengal, strategically located close to the Strait of Malacca and Singapore. Although a joint services command exists on the islands, local naval and air deployments remain limited. In short, beyond the Indian Ocean, the 'Pacific' part of Indian naval engagement in the Indo-Pacific will look stronger on paper than it does in practice.

***

The Indian Ocean is the focus of India's strategic ambition for several reasons. It occupies an influential place in both India's geography and its elite imaginations; it is the locus of India's most pressing strategic interests; and, potentially, it is also the place where India can build and lead a counter-order to China's BRI. Unlike Japan, India's strategic priorities and the intended reach of its sea power extend, to its east, only as far as the Andaman Sea.

Whether the newest iteration of the Quad will thrive where the 2007 edition failed will depend, in part, on understanding the primacy of the Indian Ocean to India and the constraints on its sea-power projection. Having raised expectations, however, the onus is now on the Indian bureaucratic and security establishments to fulfil the commitments it has already made in the Indian Ocean. India's track record in multilateral cooperation in the region is poor, and it is unclear whether existing forums - such as the Indian Ocean Rim Association, whose performance is weak, or the Indian Ocean Naval Symposium, whose achievements are more impressive - will be enough. India will also have to work on its bilateral relations with the Indian Ocean's island and littoral states. In military terms, it is imperative that India effectively build up its capabilities at sea in the Indian Ocean. This is the area where it still has tremendous relative advantage over the Chinese navy, even though Chinese naval expansion may well be narrowing this gap.

For powers outside the region seeking to engage India on maritime security issues, a sense of Indian priorities combined with a spirit of equal (or preferably, from New Delhi's point of view, junior) partnership will work better than grandiose strategic or infrastructural plans that push India beyond its ambitions and its capabilities. French President Emmanuel Macron's recent visit showed how this can be done. ${ }^{35}$

Rahul Roy-Chaudhury is Senior Fellow for South Asia at the IISS and the author of two books on India's maritime security. Kate Sullivan de Estrada is Associate Professor in the International Relations of South Asia at the University of Oxford, a Fellow of St Antony's College and a Consulting Member of the IISS.

\section{Acknowledgements}

The authors would like to thank Viraj Solanki, IISS Research Analyst for South Asia, for contributing valuable research assistance to this article.

\section{Notes}


1 Indian Ministry of External Affairs, 'India-Australia-Japan-U.S. Consultations on Indo-Pacific', 12 November 2017, http://mea.gov.in/press-

releases.htm?dt1/29110/IndiaAustraliaJapanUS_Consultations_on_IndoPacific_November_12_2017.

2 Shinzo Abe, speech to the Indian Parliament, New Delhi, 22 August 2007, http://www.mofa.go.jp/region/asia-paci/pmv0708/speech-2.html.

3 Australian Department of Foreign Affairs and Trade, '2017 Foreign Policy White Paper', November 2017, https://www.fpwhitepaper.gov.au/.

4 Demetri Sevastopulo, 'Trump Gives Glimpse of "Indo-Pacific" Strategy to Counter China', 10 November 2017, https://www.ft.com/content/e6d17fd6-c623-11e7-a1d2-6786f39ef675.

5 Indian Ministry of External Affairs, 'India-Australia-Japan-U.S. Consultations on Indo-Pacific'.

6 Louis Nelson, 'In Asia, Trump Keeps Talking About Indo-Pacific', Politico, 7 November 2017, https://www.politico.com/story/2017/11/07/trump-asia-indo-pacific-244657.

7 Ibid.

8 Indian Ministry of Defence, 'Ensuring Secure Seas: Indian Maritime Security Strategy', October 2015, p. 32,

https://www.indiannavy.nic.in/sites/default/files/Indian_Maritime_Security_Strategy_Document_25Ja n16.pdf.

9 Premesha Saha, 'The Quad in the Indo-Pacific: Why ASEAN Remains Cautious', ORF Issue Brief, no. 229, 2018, http://www.orfonline.org/research/asean-quad/.

10 Ankit Panda, 'US, Japan, India, and Australia Hold Working-Level Quadrilateral Meeting on Regional Cooperation', Diplomat, 13 November2017, https://thediplomat.com/2017/11/us-japanindia-and-australia-holdworking-level-quadrilateral-meetingon-regional-cooperation/13 November 2017.

11 Indian Ministry of External Affairs, 'India-Australia-Japan-U.S. Consultations on Indo-Pacific'.

12 White House, 'National Security Strategy of the United States of America', 2017, pp. 45-6, https://www.whitehouse.gov/wp-content/uploads/2017/12/NSSFinal-12-18-2017-0905.pdf.

13 Australian Department of Foreign Affairs and Trade, '2017 Foreign Policy White Paper'.

14 Japanese Ministry of Foreign Affairs, 'Diplomatic Bluebook 2017', p. 27, http://www.mofa.go.jp/files/000290287.pdf.

15 Indian Ministry of Defence, 'Ensuring Secure Seas', p. 32.

16 David Scott, 'The Indian Ocean as India's Ocean', in David M. Malone et al. (eds), The Oxford Handbook of Indian Foreign Policy (Oxford: Oxford University Press, 2015), p. 469.

17 Michael Pugh, 'Is Mahan Still Alive? State Naval Power in the International System', Journal of Conflict Studies, vol. 16, no. 2, 1996. See also C. Raja Mohan, Samudra Manthan: Sino-Indian Rivalry in the Indo-Pacific (Washington DC: Brookings Institution Press, 2012).

18 Scott, 'The Indian Ocean as India's Ocean', p. 468. 
19 Narendra Modi, 'Text of the PM's Remarks on the Commissioning of Coast Ship Barracuda', Port Louis, Mauritius, 12 March 2015, https://www.narendramodi.in/text-of-thepms-remarks-on-thecommissioningof-coast-ship-barracuda-2954.

20 Government of India, 'Official Spokesperson's Response to a Query on Participation of India in OBOR/BRI Forum', New Delhi, 13 May 2017, http://mea.gov.in/mediabriefings.htm?dtl/28463/Official+Spokespersons+response+to+a+query+on+participation+of+India+i n+OBORBRI+Forum.

21 P.K. Balachandran, 'India Presses for Consensus on "Indian Ocean Identity”, South Asian Monitor, 4 September 2017, https://southasianmonitor.com/2017/09/04/india-presses-consensusindian-oceanidentity/.

22 S. Jaishankar, address to the Indian Ocean Conference, Colombo, 1 September 2017, http://mea.gov.in/Speeches-

Statements.htm?dt1/28909/Foreign+Secretarys+Address+to+the+Indian+Ocean+Conference+Colomb o.

23 Balachandran, 'India Presses for Consensus'.

24 Narendra Modi, 'PM Modi's address at the inauguration of Maritime India Summit 2016', Mumbai, 14 April 2016, https://www.narendramodi.in/pm-modi-at-the-inauguration-ofmaritimeindia-summit-2016-in-mumbai-440341.

25 Rahul Roy-Chaudhury, 'India Counters China in the Indian Ocean', IISS Voices, 25 August 2017, http://www.iiss.org/en/iiss\%20voices/blogsections/iiss-voices-2017-adeb/august-2b48/indian-oceanecba.

26 Rahul Roy-Chaudhury, 'India's Perspective Towards China in Their Shared South Asian Neighbourhood: Cooperation Versus Competition', Contemporary Politics, vol. 24, no. 1, p. 107.

27 Sylvia Mishra, 'Nuclear Weapons and Capabilities in the Indian Ocean: An Indian Perspective', ORF Commentaries, 26 April 2017, http://www.orfonline.org/research/nuclearweapons-andcapabilities-in-theindian-ocean-an-indian-perspective/.

28 Indian Ministry of Defence, 'Ensuring Secure Seas’, p. 48.

29 Vice Admiral (Retd) Vijay Shankar, 'Deterrence at Sea: India's Evolving Options', IISS, London, 31 March 2017, https://www.iiss.org/en/events/events/archive/2016-a3c2/march-1194/deterrence-atsea---indias-evolvingoptions-104a.

30 Government of India, 'India-Vietnam Joint Statement During State Visit of President of Vietnam to India', 3 March 2018, http://www.mea.gov.in/bilateral-

documents.htm?dtl/29535/IndiaVietnam+Joint+Statement+during+State+visit+of+President+of+Viet nam+to+India+March+03+2018.

31 Government of India, 'Delhi Declaration of the ASEAN-India Commemorative Summit to Mark the 25th Anniversary of ASEAN-India Dialogue Relations', New Delhi, 25 January 2018, http://mea.gov.in/bilateral-

documents.htm?dtl/29386/Delhi+Declaration+of+the+ASEANIndia+Commemorative+Summit+to+m ark+the+25th+Anniversary+of+ASEANIndia+Dialogue+Relations. 
32 Saha, 'The Quad in the Indo-Pacific'.

33 Rajat Pandit, 'Eye on China: India Steps Up Naval Deployments, Kicks Off Nuclear Submarine Project', Times of India, 2 December 2017, https://timesofindia.indiatimes.com/india/eye-on-chinaindia-steps-up-navaldeployments-kicks-off-nuclear-submarines-project/articleshow/61882815.cms.

34 Rahul Roy-Chaudhury, 'India Emerges as World's Big Defence Spender', India Global Business, March 2018, http://www.indiaglobalbusiness.indiaincorporated.com/india-emergesworlds-bigdefence-spender/.

35 Government of India, 'India-France Joint Statement During State Visit of President of France to India’, 10 March 2018,

http://www.mea.gov.in/bilateraldocuments.htm?dt1/29596/IndiaFrance+Joint+Statement+during+Stat e+visit+of+President+of+France+to+India+March+10+2018. 